\title{
ABDUCTIVE REASONING AND ICT ENHANCED LEARNING: TOWARDS THE EPISTEMOLOGY OF DIGITAL NOMADS
}

\author{
Erkki Patokorpi \\ IAMSR, Abo Akademi University, Finland
}

\begin{abstract}
The core features of mobile technology are said to be mobility, interactivity, contextuality, ubiquity, pervasiveness, personalization and collaboration. These features seem to tally surprisingly well with the ideals of constructivist pedagogy. Information and communication technology -enhanced learning in general and mobile learning in particular seem to favour the abductive form of reasoning. I suggest that abduction is the mobile (or "pedestrian") form of reasoning par excellence because it meets the demands of a mobile learner envisioned by constructivist pedagogues. However, knowledge by abduction has its limitations. In addition to abduction, tacit knowledge and aura are concepts that help exploring the limits of ICT-enhanced knowledge and learning. It is suggested further that there are certain features connected to advanced mobile technologies by which one may overcome some limitations of ICT-enhanced education and edutainment. These features are multisensoriality, context-awareness and vireality (i.e. mixtures of the real and the virtual).
\end{abstract}

Key words: Technology enhanced learning, edutainment, mobile technology, nomadicity, constructivist pedagogy, abduction

\section{INTRODUCTION}

Mobile and wireless technologies are the new cutting-edge of modern information and communication technology (ICT). Educators have embraced ICT and are trying to find ways of integrating it in the curriculum as well as 
in their day-to-day teaching. Concepts like mobility and edutainment challenge the old pedagogical principles and practices as educators combine modern ICT with constructivist ideals of learning. Some visionaries claim that we are all turning into nomads (Keen and Mackintosh, 2001; Carlsson and Walden, 2002; Kleinrock, 2001; Sørensen, 2002; 2003). In a nomadic culture learning does not take place in the classroom but wherever one is in need of relevant information or new skills. Yet it is not clear how the new ICT will (if at all) change the ways we perceive the world around us, and how educators could or should use the new tools?

This paper is the first approximation of a larger research project, consisting of five research articles. The topic of each individual article belongs to a well-established field of scientific research. Each numbered section in this paper corresponds to one future research article. The first section discusses the claim, made by some influential computer science and information systems researchers, that we are on the threshold of a new paradigm of digital communication and computing - true digital nomadicity. Section two presents the credo of constructivist pedagogy, and its relation to technology enhanced learning. The third section introduces abductive reasoning, and argues that it is the most central inferential mechanism at work in interaction taking place in advanced ICT environments in general and in mobile environments in particular. Section four charts the limits of digital objects and interaction with the assistance of three philosophical concepts: abduction, tacit knowledge and aura. Section five briefly examines the features of the emerging paradigm of digital interaction. The features examined are: context-awareness, multisensoriality and vireality. Taken together these topical fields make up a motley crew whose mutual implications are hard to account for or verify. Abduction is the primary unit of analysis, tying all these topics together. Abduction enables crossing over disciplinary boundaries and at the same time retaining an acceptable level of scientific rigour. In summary the paper proposes a focal area of future enquiry along with tentative methodological recommendations.

\section{WHAT DO THE TECH VISIONARIES MEAN WHEN THEY TALK ABOUT DIGITAL NOMADS?}

It is becoming extremely clear that some key concepts used in computer science and information systems literature - most notably those of nomadicity, mobility and interaction - cannot any more satisfactorily capture the present-day reality of advanced mobile technology environments. Although we are still partly trapped in the old world of fixed computing 
platforms, accessed by users with the same (personal) device from the same IP address, the world of radical mobility - true nomadicity - is just round the corner (see esp. Kleinrock, 2001). Peter Wegner (1997), Carsten Sørensen (2002; 2003) and Leonard Kleinrock (2001), among others, have aspired to describe and explain the workings of this paradigm shift from a strapped mobility to truly nomadic digital environments.

"We are all nomads," says Leonard Kleinrock in an article that was published in 1996. And he continues: "but we lack the systems support to assist us in our various forms of mobility" (p. 351). For Kleinrock, nomadicity means two different things. First, nomadicity implies the technological capability to deal with temporary disconnectedness, caused by movement from one connected place to another connected place, and second, the seamless and transparent technological support for nomads, for whom being on the move is the normal state of affairs. In a more recent paper, Kleinrock (2001) starts off with the assumption that most users of computing, communication and services are people on the move, and here he systematically uses the word nomadicity to refer to a phenomenon in which the state of being on the move is the normal state and not a break from the normal. Kleinrock underlines the need for a better infrastructure and a more advanced system support for nomadic users so that the computing environment adjusts itself to the user rather than the other way round. Computing should become as transparent and convenient a product as electricity (on the utility model see Rappa, 2004). According to Kleinrock, we are on our way to a world of true nomadicity.

Portable computing - in the form of laptops, mobile phones, PDAs and handheld computers - set the so-called knowledge workers free from the physical confines of the office. Along this line of thought, mobility has traditionally meant the ability of the user to move anywhere, anytime and yet stay connected, independently of the geographical constraints. For instance, Kopomaa (2000) talks about urban nomads and their "placeless use" of mobile devices. This kind of mobility Kakihara and Sorensen $(2001 ; 2002)$ call spatial mobility: people in the post-industrial era are geographically independent "nomads" supported by various technologies.

Let us call it contextual mobility when context is, in some form, taken into account. Positioning (e.g. GPS, GLONASS, Galileo) is the single most important technology that makes contextual mobility possible (see e.g. Spriestersbach and Vogler, 2002; Priyantha et al., 2001; Liljedal, 2002). In other words, the location where the device is being used has an important impact on the nature of the information presented and on the whole 
interaction. All the same, this type of discussion focuses on the technological aspects of mobility. Some writers take a step further, trying for instance to make sense of both persons and devices moving in space (see e.g. O'Hare and Gregory, 2000; Floch et al., 2001), and of the value that such technologically supported connectedness while moving creates in $\mathrm{m}$ commerce or in work (Anckar and Eriksson, 2003).

To sum up so far, in the early days of mobility, most mobile applications still sought to hide the location of use. Mobility implied first of all being able to move anywhere, anytime and still staying connected - to be able to stay happily oblivious about location. In contrast, context-aware design, to name one example, tries to exploit location, making some aspects of it an integral part of the interaction between the user, the mobile system and the mobile device. Sørensen and his associates (2002; 2003; Kakihara and Sørensen, 2001; 2002; Pica and Kakihara, 2003) have vigorously propagated for an even more expanded view on mobility, one which would better take into account the fact that not just devices and persons move but that also objects, spaces and symbols do so. This fact entails that over and above the spatial context, we consider the social and virtual contexts of use.

Researchers consistently stress the importance of personalization as the key to enhanced usability of mobile services. When machines universally talk to one another, personalized user interfaces seem to be the only way to reasonably well cater for individual information and service needs (Omojokun and Isbell, 2003). Unfortunately, at the same time as context is becoming more important than ever, our personalization techniques have seen little progress (Lyytinen and Yoo, 2002; Sørensen, 2002).

Traditionally computability is seen in line with the algorithmic model. According to Peter Wegner (1997), equating computability with the behaviour that Turing machines are able to do (i.e. to compute mathematical functions), falls short of satisfactorily describing the behaviour of objectoriented and distributed or decentralized multiagent systems. Peter Wegner and Dina Goldin (1999; Goldin and Wegner, 2004) say that the interaction of this sort of advanced computing systems is similar to dialogue, questionanswering and two-person games in the sense that inputs are dynamically dependent on prior outputs, whereas in a Turing machine the inputs are history-independent and reproducible. Keil and Goldin (2003) characterize decentralized multiagent systems as open systems that are constructed and constrained by the environment rather than designed. A termite colony is an example of a decentralized multiagent system in nature. Without design (i.e., an internal representation of a shared goal) as well as without a capacity for 
planning and coordination, the termites as a colony are capable of building a nest. If Wegner and his colleagues are right, we have to revise our thinking not only of human-computer interaction but also of interaction within computers and computing systems.

The term ubiquity (Lat. ubique, everywhere) conveys the idea that computing will be available in all places and at all times. Ubiquitous computing and communication means intelligent environments in which various distributed computing units are linked together by heterogeneous communication links (see e.g. Abowd and Mynatt, 2000). Ubiquitous mobile computing, in order to be really ubiquitous, entails that different networking technologies work seamlessly together (see e.g. Chen and Petrie, 2003). Ubiquitous computing is not the same thing as nomadic computing. The term nomadicity implies that the user carries the technology with him/her, whereas ubiquity implies that the world itself is computerized. Presently, these two lines of development are converging. Other terms related to ubiquitous and nomadic computing are for instance ambient intelligence, distributed and context-aware systems, tangible interaction, mobile informatics and pervasive computing (Lyytinen and Yoo, 2002).

It seems plausible that the recent developments described above constitute a new paradigm, although we are still missing a common theoretical ground, by the help of which to make sense of it. It means that the epistemological conditions have changed or are changing, too. As I try to argue in the course of the project, abduction will play a central part in the new world of digital nomads.

\section{CONSTRUCTIVIST PEDAGOGY AND ICT ENHANCED LEARNING - A MATCH MADE IN HEAVEN?}

It is generally claimed by educationalists that ICT mediated, and especially mobile, learning realizes the central ideals of constructivist pedagogy. In modern constructivist learning theories, knowledge is seen essentially as a social phenomenon; a social construct. Because the learner builds on his prior knowledge and beliefs as well as on the knowledge and beliefs (and actions) of others, learning needs to be scrutinized in its social, cultural and historical context (Piaget, 1975; Piaget and Inhälder, 1982; Vygotsky, 1969; Leontjev, 1977; Engeström, 1987; Tynjälä, 1999; Järvinen, 2001). According to Järvinen (2001), technology-enhanced learning supports "naturally" learning by manipulation (e.g. trial and error), comparison and 
problem solving in a non-prescriptive real-world-like context that leaves room for creative thinking and innovation.

Recent research literature indicates that there is a fairly clear consensus on the central features of modern constructivist methodology (see e.g. Järvinen, 2001; Tynjälä, 1999; Ahtee and Pehkonen, 1994; Johansson, 1999; Poikela, 2002). First of all, constructivist pedagogues underline the importance of a larger goal that organizes smaller tasks into a sensible whole, giving an incentive to take care also of the less exciting intermediate routines. Consequently, constructivist learning usually takes the form of a project (e.g. Pehkonen, L., 1994). Learning is not focused on separate facts but on a problem. The learner needs to feel that the problem in some way concerns him (i.e. to own the problem) in order to be motivated to try to solve it. The problem should be close to a problem in the real world. When dealing with a real-world problem the student turns straight to information sources in the real world instead of trying to figure out what one would do if this were a real situation (see e.g. Kanet and Barut, 2003; Leino, 1994). Unlike in traditional teaching, in constructivist learning there is no one right answer but many possible solutions to a problem or at least if there is one right solution, there are many alternative routes to it.

It follows from what has been said above that it is the learner and not the teacher who needs to take in a significant degree the responsibility for gathering knowledge. The learning environment, too, should be in some sense similar to a real-world environment. This usually means going out from the traditional classroom, and learning things in their authentic environment (see e.g. Lehtonen, 2002). The learner's prior knowledge, experience and skills should be taken into account. Even if the learning materials was not something practical but facts or abstract concepts, the learner will better understand and remember them if they are built on his prior knowledge and experience (e.g. Ahtee, 1994; Haapasalo, 1994). People are different, with different experiences, skills, interests and goals. Constructivist education seeks to take this fact into account by leaving room for alternative individual learning strategies.

Constructivists underline the social aspect of learning; all forms of interaction are encouraged, and usually assignments involve teamwork or other forms of cooperation. Consequently, communication with peers and outsiders is also encouraged, unlike in traditional teaching where consulting one's neighbor is usually considered cheating. The demand for iteration is based on the conception that knowledge is not something ready-made and static but an ongoing process. The learners need to retrace their steps and 
constantly revise their knowledge and skills in interaction with their environment. Constructivist learning is thus usually constructed in a form that allows a cyclic movement, that is, a possibility to return to earlier stages or to review intermediate results. When the learning process itself is more important than the outcome, it follows that evaluation should focus on the process rather than the outcome (Björkqvist, 1994). The final feature stressed by constructivist pedagogues is guidance. In constructivist learning methodology traditional teacher monologue ex cathedra is replaced by guidance, in which the teacher's role is to facilitate learning by giving pieces of advice and guiding onto the right direction.

A cursory look at what teachers say about the practical use of ICT in education indicates that ICT enhanced learning seems exceptionally well to tally with the constructivist ideals. According to Sotillo (2003), "[n]ew developments in wireless networking and computing will facilitate the implementation of pedagogical practices that are congruent with a constructivist educational philosophy. Such learning practices incorporate higher-order skills like problem-solving, reasoning, and reflection". Arja Puurula (2002) claims that teaching by virtual environments (or telematic teaching) has a number of advantages over more conventional methods. It seems that the students cooperate more, work more intensively and are more motivated than in conventional classroom teaching. Telematic teaching is an efficient equalizer, leveling regional and social inequalities (see also e.g. Hussain et al., 2003). Langseth (2002) stresses creativity and the fact that the pupils take responsibility for their own work, and, instead of using their logical and linguistic faculties, use a "broader range of intelligences according to their personal preferences" (pp. 124-125). Langseth continues: "The web offers individuality in the sense that you can choose your own pace, your own source of information, and your own method; in a group or alone" (p. 125; see also e.g. Kurzel et al., 2003). One more general point made by teachers is that the focus is on collaborative work, not on the final product. These views are probably representative of the enlightened popular idea of the matter. All in all, ICT-enhanced teaching is supposed to be more democratic, more personal, give broader skills, more creative, more interactive, and so forth. We could say that constructivist pedagogy and ICT mediated knowledge and learning seem to have at least the following general features in common: the construction of personal meaning; an incentive to collaboration; the learner is mainly responsible over the information seeking process; learning by doing (i.e. praxis over theory).

In recent literature, the earlier claims that e-learning saves time and makes learning more efficient have been challenged (see e.g. Eales, 2004; 
Judge, 2004). Nevertheless, the general opinion among constructivist pedagogues seems to be that the ICT-mediated learning and the constructivist educational doctrine is a match made in heaven. And, at least on the surface, so it seems. Furthermore, it seems that the features associated with both constructivist learning and the new technologies used for supporting that learning - democratic, personal, skilled, creative and interactive - are also used for describing knowledge by abduction.

\section{THE LOGIC OF SHERLOCK HOLMES IN LEARNING THROUGH TECHNOLOGY}

Sherlock Holmes, the hero of Arthur Conan Doyle's novels, often amazed his loyal friend Dr. Watson by drawing a correct conclusion from an array of seemingly disparate and unconnected facts and observations. The method used by Sherlock Holmes is abduction. Abduction is inference to the best explanation. Here is an example of abduction from Charles Sanders Peirce $(1996 ; 2001)$ :

All beans from this bag are white.

These beans are white.

Therefore, these beans come from this bag.

The inference is not formally (i.e., deductively or analytically) valid because the beans could come from somewhere else - but this form of reasoning conveys the manner in which people reason when making discoveries in the sense of coming up with new ideas. Abduction is considered a logic of discovery.

As a logic of discovery, abduction is essentially a matter of finding and following clues. However, a clue alone is not enough (Peltonen, 1999). A clue leads the reasoner to something that he already knows. The observation of a clue is in relation to the observer's background knowledge. In other words, clues without models or theories are useless. Abduction, in contrast to the mere following of clues, aims at eliciting new knowledge. One cannot become an adept detective, that is, skilful in finding clues, by following rules. The semiotic (i.e., dealing with signs, symbols, clues) paradigm of knowledge does not deal with a disciplined regulation of coded knowledge, yet the clues are there for all to see. However, the clues that are there for all 
to see are qualitative and unique. They cannot be measured and regulated. This sets the stage for knowledge that is essentially personal. It is personal in the sense that individuals differ in their ability to detect clues, due to individual differences in their prior knowledge and experience as well as logical acumen (see e.g., Ginzburg, 1989; Peltonen, 1999).

Abduction seems to be central to the form of knowledge used in ICT enhanced learning. According to the Italian microhistorian Carlo Ginzburg, certain sciences or disciplines typically allow or call for interpretation and the searching of clues. Ginzburg calls them symptomatological sciences. Medicine, history, physical astronomy, geology, palaeontology, physical anthropology, ethnography, archaeology belong to the symptomatological sciences. These disciplines could also be called - at least in their $19^{\text {th }}$ Century form - private detective sciences (Ginzburg, 1989). These disciplines embraced the semiotic paradigm based on the searching of clues or symptoms.

So, there seems to be an area of knowledge that suits or calls for the form of reasoning called abduction and for the way of retrieving knowledge that accompanies it. It seems that abduction is also admirably suitable for describing and explaining the special epistemological circumstances of modern ICT mediated learning. Abduction is not yet fully understood but it certainly seems a better conceptual tool than descriptive adjectives like "mobility" and "ubiquity" that are presently used in mobile technology research. It is better because: First, abduction is a single (as well as rigorous and well-defined) unit of analysis, allowing one to analyse and compare diverse phenomena with good scientific accuracy. Second, abduction catches the gist of how humans reason under uncertainty in a context. Abduction, as a scientific tool, brings to mind fuzzy logic, which was at first an outcast but has by now proved its scientific worth and practical potential. An advanced mobile computing situation calls for, or even compels to, the use of abductive reasoning.

The use of abduction offered here is twofold. First, abduction is an analytical tool that will explain certain features of mobile technology. Second, abduction is probably the central inferential mechanism at work when learners learn in an ICT or mobile context. 


\section{WHAT OBJECTS MADE OF BITS AND BYTES CANNOT DO: ABDUCTION, AURA AND TACIT KNOWLEDGE}

In the same way as traditional classroom teaching sets boundaries to what and how learners can learn there seem to be some limitations to ICTenhanced and mobile knowledge, that is, limitations or conditions set by elearning and m-learning environments. A brief look will be taken below at these limitations with the help of three well-known philosophical concepts: abduction, aura and tacit knowledge.

The armchair approach of Sherlock Holmes (i.e., abduction) does not work in all cases but has its limitations. Some avenues of investigation require systematic observations and induction; or deduction; or experiments, using expensive special machinery or other equipment; special skills, and so forth. The construction of a personal meaning goes at times against the objectives of more traditional educational principles, which include the dissemination of uniform knowledge and eradication of false conceptions. Especially as a result of the immense increase in information, the eradication of erroneous conceptions has become one of the most important and most difficult tasks of today's teachers.

Aura, in turn, gives expression to the intuition that a copy (even a perfect copy) of Leonardo Da Vinci's Mona Lisa is not the same thing as the original. The concept of aura is Walter Benjamin's attempt to put a finger on the inimitable qualities that an original object has (or is supposed to have). Walter Benjamin's defence of the unique was a reaction to the expansion of the reproductive industries into art in the early $20^{\text {th }}$ Century. He tried to find the unique features of a work of art in photography, too, so that photography could enter the realm of the unique. Reproduction, or copying, destroys the unique in things, that is, it destroys their aura. An object has a history and a patina. Patina is a number of physical traces which can be detected for instance by chemical analysis. A history of an object consists for instance of a known record of the people that have owned the object and places that it has been in. Unique traces guarantee an object's authenticity. With technical reproduction like photography authenticity cannot be ascertained. To have an aura is to be unique (Benjamin, 1991).

Benjamin posits aura in the things themselves. This is difficult to accept. Following Matti Peltonen (1999), the present writer unceremoniously rejects Benjamin's habit of positing meanings in objects themselves. It is rather human beings that posit meanings in objects. The romantic idea of the 
uniqueness of artefacts and the uniqueness of individual artists and their genius lies at the bottom of this thought construction. Its heyday was especially in the Renaissance and the modern era. Aura is rather a historical construction; an idea, an attitude, and a practice that has a historical origin, and therefore a historical end as well. The idea of aura rests on the wellknown social and economic structures of the art market. Quite as easily the unique features (aura) may lose their value in the eyes of the beholder and in the social and economic system. Photography, Warhol's reproductive art, digital products which can be copied and reproduced perfectly may be steps towards a different way of seeing works of art and other "unique" objects. The young generations may well constitute a public with a different sensibility.

Some knowledge is tacit, i.e. knowledge that cannot be communicated verbally: we know more than we are able to tell. According to Michael Polanyí $(1964 ; 1967)$, knowledge is a human construction, and although it is public, it is at the same time to a great extent personal. Knowledge is personal in the sense that our emotions and experiences are an important and inescapable part of our knowledge. However, the language, concepts and intellectual tools we use when processing our experiences come from the social and linguistic community (i.e., from other people) whose members we are. The concepts we inherit and use always have a tacit dimension. Some knowledge, like special skills, has a large proportion of tacit knowledge. It follows that to mediate tacit knowledge, practical or physical interaction with people, machines and objects in time and place are required.

Especially in terms of its collaborative potential, ICT-mediated learning enhances the mediation of skills (and thus the transference of tacit knowledge) whenever the learner gets practical guidance by a human collaborator (via a computation element) or built-in machine guidance. It seems plausible that there is a limit (which can be approached but never quite reached) to how well tacit knowledge can be mediated purely by ICT without the subject being on the spot in flesh and blood. Shapin and Schaffer (1989) as well as Collins and Kusch (1998) have illuminated the immense difficulties in repeating from a distance - that is, without hands-on guidance - a scientific experiment that involves more or less complicated equipment. Online shopping is another example. It is common knowledge that online customers need to feel the fabric, smell the flowers and kick the tyres in order to be persuaded to buy something. 


\section{THE NEW-PARADIGM FEATURES: CONTEXT- AWARENESS, VIREALITY AND MULTISENSORIALITY}

Context-awareness, multisensoriality and vireality force us rethink especially the effects of mobile technologies in various walks of life. The present author has coined the word "vireality" to refer to a certain kind of mixture of the real and the virtual. The above, selected features seem to mark the beginning of a second era (a new paradigm) of very advanced ICT in general and mobile technology in particular, transgressing the earlier limits. Although the current infrastructure does not support such advanced (especially mobile) environments on any larger scale, it is possible to envision such an environment being fully functional. Consequently, this part of the paper is futuristic in nature, and will focus on the key enabling technologies of nomadic and ubiquitous computing environments.

Context-awareness refers to the knowledge that can be read from the user's environment, including all sorts of devices and information that are to be found in that environment. Context-aware systems are thus systems in which the devices are to some extent aware of their own status, the user status, the surroundings, and (possibly) other devices in the surroundings (Bellavista et al., 2003). Intuitively the demands of context are not too difficult to grasp. Robert Filman in his editorial in IEEE Internet Computing puts it nicely:

If someone approaches you in Times Square and asks if you know how to get to Carnegie Hall, for example, you don't answer, "Yes." Rather, you take account of the question's context. You might consider the weather or seek information (or infer from age and dress) on whether the questioner prefers the subway, a taxi, or walking. People are context-aware in their service responses - and more concerned with intent than literal interpretation (Filman, 2003).

The conclusion one can draw from this is that future systems will need to be able to have conversations. This pressure to make systems increasingly human-like is particularly felt in context-aware mobile systems. Examples of context-aware applications include active maps that automatically change as the user moves (Schilit et al., 1994); applications for the orientation of device position indoors (Bahl et al., 2000) and outdoors (Priyantha et al., 2000) or for both, as the Cyberguide (Abowd et al., 1996) and the REAL (Baus et al., 2001). 
Virtual reality is "a computer generated interactive, three-dimensional environment in which a person is immersed" (Aukstakalnis, 1992). To take a step further towards virtuality, systems or environments that extend parts of the real world with virtual elements are called augmented realities or augmented reality systems. It is possible to create virtual environments that are based on metaphors instead of scientific theories or models. These virtual models can be realized in the computer environment without any need to verify them against the physical reality (Turoff, 1997). The ability to "opportunistically" and at will to mould virtual environments is seen as the most valuable function of virtuality in computing systems (see e.g. O'Hare, 2000).

The tangible User Interface (TUI) is a major step towards a more advanced digital environment with a more balanced combination of the real and the virtual. TUI combines physical objects and physical space with virtual elements. So-called Tangible Bits allow haptic (i.e., grasp and manipulate) interaction with physical objects, exploiting, too, the mediation of information by versatile sensory input from the background. Examples of this include such display media as light, sound and airflow, which exert their impact on the more peripheral senses. Tangible Bits thus copies the rich potential of the division between foreground and background of awareness in regular human activity in the real world. Here one could talk about ambient intelligence, which makes the environment intelligent by extending and augmenting space with digital information and objects. This vision of augmented reality by TUI turns walls and tables into interface surfaces, coupling graspable objects like books with digital information as well as exploiting other senses than vision (e.g. touch by airflow) in communication. With TUI, computing will become "truly ubiquitous" (Ishii and Ullmer, 1997), an integral, although invisible, part of our everyday environment.

The development of context-aware systems and augmented reality gets a boost from sensor technologies. Today we have a rich supply of minuscule, very cheap sensors - so-called sentient objects. Sentient objects interact with the physical environment, making applications "aware" of the physical space they occupy. Sentient objects, which are especially important in mobile environments, extend the possibilities of communication and flow of information between machines and humans further (see e.g. Biegel and Cahill, 2003). As a result, the scope of the semiotic paradigm of knowledge gets wider. The resultant environment is artificial (compared to a natural environment) in the sense that the experiential (e.g. learning) materials can to a greater extent than before be trumped up, arranged and manipulated by the users or by others. 


\section{CONCLUSION}

The train of thought presented in this paper proceeds as follows: ICTenhanced learning realizes the central ideals of constructivist pedagogy. Abduction goes a long way towards describing and explaining the special epistemological circumstances of ICT-enhanced interaction and learning. ICT cuts out aspects of knowledge and reality, making abduction at some point inoperable. Aura and tacit knowledge, too, help in marking out the limits of discursive means via abduction (i.e., semiotic means). Contextawareness, multisensoriality and vireality (a balanced mixture of the real and the virtual) broaden the potential of abduction (i.e., the semiotic paradigm of knowledge). These three selected, new-paradigm features broaden the scope of abductive reasoning because they bring us (as users) a step closer to kicking tyres and feeling the fabric.

\section{REFERENCES}

Abowd, G.D. and E.D. Mynatt (2000), Charting past, present, and future research in ubiquitous computing, ACM Transactions on Computer-Human Interaction, 7(1), 29-58.

Ahtee, M. (1994), The development in teaching of physics, in Ahtee, M. and Pehkonen, E. (eds.), 43-50.

Ahtee, M. and Pehkonen, E. (eds.) (1994), Constructivist Viewpoints for School Teaching and Learning in Mathematics and Science, Research Report 131. Yliopistopaino, Helsinki.

Anckar, B. and N. Eriksson (2003), Mobility: The Basis for Value Creation in Mobile Commerce? Proceedings of the SSGRR 2003s Conference, L'Aquila, Italy.

Aukstakalnis, S. and D. Blatner, S.F. Roth (1992), Silicon Mirage: The Art and Science of Virtual Reality, Peachbit Press.

Bahl, P. and V. N. Padmanabhan (2000), Radar: An in-building rf-based user location and tracking system, Proceedings of the IEEE Infocom, Tel-Aviv, Israel.

Baus, J. and C. Kray, A. Krüger, W. Wahlster (2001), A Resource-Adaptive Mobile Navigation System, online at http://w5.cs.uni-sb.de/ krueger/papers/iui2002.pdf accessed 22.04.2003.

Bellavista, P. and A. Corradi, R. Montanari, C. Stefanelli (2003), Dynamic Binding in Mobile Applications: A Middleware Approach, IEEE Internet Computing. 7(2), 34-42.

Benjamin, W. (1991), Bild och dialektik, Brutus Östlings bokförlag Symposion Ab: Stockholm.

Biegel, G. and V. Cahill (2003), Sentient Objects: Towards Middleware for Mobile, Contextaware Applications, in European Research Consortium for Informatics and Mathematics, ERCIM News No. 54.

Björkqvist, O. (1994), Social constructivism and assessment, in Ahtee, M. and Pehkonen, E. (eds.), 19-26.

Carlsson C., P. Walden (2002), Mobile Commerce: Some Extensions of Core Concepts and Key Issues, Proceedings of the SSGRR International Conference on Advances in Infrastructure for e-Business, e-Education, e-Science and e-Medicine on the Internet, L'Aquila, Italy. 
Chen, Y-F.R. and C. Petrie. (2003), Ubiquitous Mobile Computing, IEEE Internet Computing, 7(2), 16-17.

Collins, H. and M. Kusch (1998), The shape of actions: what humans and machines can do, Cambridge (Mass.), MIT Press.

Eales, R. T.J. (2004), Crossing the Border: Comparing Partial and Fully Online Learning, in e-Society 2003, IADIS International Conference, 218-225.

Engeström, Y. (1987), Learning by Expanding, Orienta-Konsultit Oy, Helsinki.

Filman, R.E. (2003), Do You Know How to Get to Carnegie Hall? IEEE Internet Computing, March and April, 4-5.

Floch, J. and S. Hallsteinsen, A. Lie, H.I. Myrhaug (2001), A Reference Model for ContextAware Mobile Services, online at www.nik.no/2001/06-floch.pdf accessed 29.07.2003.

Ginzburg, C. (1989), Ledtrådar. Essäer om konst, förbjuden kunskap och dold historia, Stockholm: häften för kritiska studier.

Goldin, D., P. Wegner (2004), The Origins of the Turing Thesis Myth, Brown University Technical Report CS-04-13.

Haapasalo, L. (1994), Model for construction and assessment of conceptual and procedural knowledge, in Ahtee, M. and Pehkonen, E. (eds.), 87-92.

Hussain, H. and Embi, Z.C., Hashim, S. (2003), A Conceptualized Framework for Edutainment, Informing Science: InSite - Where Parallels Intersect, 1077-1083.

Ishii, H. and B. Ullmer (1997), Tangible Bits: Towards Seamless Interfaces between People, Bits and Atoms, online at http://www.acm.org/sigchi/chi97/proceedings/paper/hi.htm accessed 24.07.2003.

Järvinen, E-M. (2001), Education about and through Technology. In search of More Appropriate Pedagogical Approaches to Technology Education, Acta Universitates Ouluensis, E 50. Oulun yliopisto, Oulu.

Johansson, K. (1999), Konstruktivism i distansutbildning. Studerandes uppfattning om konstrukivistisk lärande. Umeå universitet, Umeå.

Judge, M. (2004), The Wired for Leaming Project in Ireland. A Classic Tale of Technology, School Culture and the Problem of Change, in e-Society 2003, IADIS International Conference, 226-235.

Kakihara, M. and C. Sørensen (2001), Expanding the 'mobility' concept, ACM SIGGROUP Bulletin archive. 22(3), 33-37.

Kakihara, M. and C. Sørensen (2002), Mobility: An Extended Perspective, in Proceedings of the Hawai'i International Conference on System Sciences, Big Island, Hawaii.

Kanet, J.J. and Barut, M. (2003), Problem-Based Learning for Production and Operations Management, Decision Sciences, A Journal of Innovative Education. Volume 1, Number 1, Spring, 99-114.

Keen, P.G.W. and R. Mackintosh (2001), The Freedom Economy: Gaining the MCommerce Edge in the Era of the Wireless Internet, New York: Osborne/McGraw-Hill.

Keil, D. and D. Goldin (2003), Modelling Indirect Interaction in Open Computational Systems, in Proceedings of the Twelfth IEEE International Workshops on Enabling Technologies: Infrastructure for Collaborative Enterprises (WETICE'03), Linz, Austria.

Kleinrock, L. (1996), Nomadicity: Anytime, anywhere in a Disconnected World. Mobile Networks and Applications. 1, 351-357.

Kleinrock, L. (2001), Breaking Loose. Communications of the ACM, 44(9), 41-45.

Kopomaa, T. (2000), The City in Your Pocket. Birth of the mobile Information Society, Gaudeamus: Helsinki.

Kurzel, F. and Slay, J., Hagenus, K. (2003), Personalising the Learning Environment, Informing Science: InSite - Where Parallels Intersect, 589-596. 
Langseth, I. (2002), Sense of Identity, Karppinen, S. (ed.),123-128. Neothemi-Cultural Heritage and ICT at a Glance, Studia Pedagogica 28, Helsinki: Hakapaino.

Lehtonen, H. (2002), Oppimisen halu ja opiskelu, Poikela, E. (ed.), Ongelmaperustainen pedagogiikka: Teoriaa ja käytäntöä. Tampere University Press, Tampere, 148-161.

Leino, J. (1994), Theoretical considerations on constructivism, Ahtee, M. and Pehkonen, E. (eds.), 13-18.

Leontjev, A.N. (1977), Toiminta, tietoisuus, persoonallisuus. Kansankulttuuri, Helsinki.

Liljedal, A. (2002), Design Implications for Context Aware Mobile Games, online at www.interactiveinstitute.se/mobility/Files/Master\%20Thesis.pdf accessed 18.02.2003.

Lyytinen K., Y. Yoo (2002), Issues and Challenges in Ubiquitous Computing. Communications of the ACM, 45(12), 63-65.

Lyytinen, K., Y.Yoo (2002), Research Commentary: The Next Wave of Nomadic Computing, Information Systems Research. 13(4), 377-388.

O'Hare, G.M.P. (2000), Agents, Mobility and Virtuality: A Necessary Synergy. Proceedings of International ICSC Symposium on Multi-Agents and Mobile Agents in Virtual Organisations and E-Commerce-MAMA.

Omojokun, O. and C.L. Isbell Jr. (2003), User Modeling for Personalized Universal Appliance Interaction. Proceedings of the 2003 Conference on Diversity in Computing, 65-68.

Pehkonen, L. (1994), Project work - a way to learn actively, Ahtee, M. and Pehkonen, E. (eds.), 161-164.

Peirce, C.S. (1996), Collected Papers 1931-58, C. Hartshorne, P. Weiss and A. Burks. (eds.), Cambridge (Mass.): Harvard University Press.

Peirce, C.S. (2001), Johdatus tieteen logiikkaan: ja muita kirjoituksia. Tampere: Vastapaino.

Peltonen, M. (1999), Mikrohistoriasta, Helsinki: Gaudeamus.

Piaget, J. (1982), The Essential Piaget. Routledge, Kegan \& Paul, London.

Piaget, J. and Inhälder, B. (1975), Die Entwicklung des räumlichen Denkens beim Kinde. Gesammelte Werke 6. Studienausgabe. Ernst Klett Verlag, Stuttgart.

Pica, D. and M. Kakihara (2003), The Duality of Mobility: Designing Fluid Organizations through Stable Interaction, The 11 th European Conference on Information Systems (ECIS 2003), Naples, Italy.

Poikela, E. (ed.) (2002), Ongelmaperustainen pedagogiikka: Teoriaa ja käytäntöä. Tampere University Press, Tampere.

Poikela, E. and Nummenmaa, A.R. (2002), Ongelmaperustainen oppiminen tiedon ja osaamisen tuottamisen strategiana, Poikela, E. (ed.), Ongelmaperustainen pedagogiikka teoriaa ja käytäntöä. Tampere University Press, Tampere.

Polanyí, M. (1964), Personal knowledge: towards a post-critical philosophy, New York: Harper Torchbooks,.

Polanyí, M. (1967), The tacit dimension. London : Routledge \& Kegan Paul.

Priyantha, N.B. and A.K.L., Miu, H Balakrishnan, Teller, S. (2001), The Cricket Compass for Context-Aware Mobile Applications. MIT Laboratory for Computer Science, online at http://nms.lcs.mit.edu/papers/CricketCompass.pdf accessed 18.02.2003.

Puurula, A. (2002), Searching for a pedagogical basis for teaching cultural heritage using virtual environments, Karppinen, S. (ed.), 17-32. Neothemi-Cultural Heritage and ICT at a Glance. Studia Pedagogica 28, Helsinki: Hakapaino.

Rappa, M. (2004), The Utility Business Model and the Future of Computing Services, IBM Systems Journal, 43(1), 32-42.

Schilit, B. and N. Adams, R. Want (1994), Context-aware computing applications, IEEE Workshop on Mobile Computing Systems and Applications, Santa Cruz, CA, US. 
Shapin, S. and S. Schaffer (1989), Leviathan and the air-pump: Hobbes, Boyle, and the experimental life, Princeton (NJ): Princeton University Press.

Sørensen, C. (2002), Digital Nomads and Mobile Service, Receiver. Vodafone, online at www.receiver.vodafone.com accessed 11.12.2004.

Sørensen, C. (2003), Research Issues in Mobile Informatics: Classical Concerns, Pragmatic Issues and Emerging Discourses, Workshop on Ubiquitous Working Environment at Weatherhead School of Management, Case Western Reserve University, Cleveland Ohio, USA, K. Lyytinen \& Y. Yoo (eds.), online at is.lse.ac.uk/staff/sorensen/downloads/Sorensen2003.pdf accessed 5.1.2005.

Sotillo, S.M. (2003), Pedagogical Advantages of Ubiquitous Computing in a Wireless Environment, Case Studies, May/June 2003, online at: http://ts. mivu.org/default.asp? show=article\&id $=950$ accessed 25.5.2004.

Spriestersbach, A. and H. Vogler (2002), Location-Awareness for Improving the Usability of Mobile Enterprise Applications, SAP AG and SAP Labs, online at http://www.sapdesignguild.org/community/readers/reader_mobile.asp accessed 18.02.2003.

Turoff, M. (1997), Virtuality, Communications of the ACM, September 1997/Vol. 40. No. 9 , $38-43$.

Tynjälä, P. and L. Helle, K. Lonka, M. Murtonen, J. Mäkinen, Olkinuora, E. (2001), A University Studies Perspectives into the Development of Professional Expertise, in Pantzar, E. and R. Savolainen, P. Tynjälä (eds.), In Search for a Human-Centred Information Society, Tampere University Press, Tampere, 143-170.

Tynjälä. P. (1999), Oppiminen tiedon rakentamisen. Konstruktivistisen oppimiskäsityksen perusteita, Tammer-Paino Oy, Tampere.

Vygotsky, L.S. (1969), Denken und Sprechen, Fischer, Frankfurt am Main.

Wegner, P. (1997), Why Interaction Is More Powerful than Algorithms? Communications of the ACM, 40(5), 81-91.

Wegner, P. and D. Goldin (1999), Interaction, Computability, and Church's Thesis. Draft, online at http://www.cse.uconn.edu/ dqg/papers/ accessed 29.10.2004. 